\title{
Diagenesis and its impact on reservoir quality for the Chang 8 oil group tight sandstone of the Yanchang Formation (upper Triassic) in southwestern Ordos basin, China
}

\author{
Weibing Lin ${ }^{1,2} \cdot$ Lin Chen ${ }^{3}$ Yongchao $\mathrm{Lu}^{1,2} \cdot$ Haiyan $\mathrm{Hu}^{4} \cdot \mathrm{Lu} \mathrm{Liu}^{5} \cdot$ \\ Xiaochen Liu ${ }^{1,2} \cdot$ Wei Wei ${ }^{1,2}$
}

Received: 12 October 2016/Accepted: 12 March 2017/Published online: 22 March 2017

(C) The Author(s) 2017. This article is an open access publication

\begin{abstract}
Based on the applications of thin section, cathode luminescence, scanning electron microscope and X-ray diffraction, this paper studies the reservoir characteristics, diagenesis features and their influences on the development of reservoir pores for the Chang 8 oil group of Yanchang Formation in southwestern Ordos Basin. Results show that the reservoir is characterized by low composition maturity, low structure maturity, low porosity/ultra-low porosity and ultra-low permeability which belong to tight reservoir. The reservoirs develop medium intensity of compaction, moderate to strong cementation, relatively strong dissolution, suggesting that it is in stage $\mathrm{B}$ of the middle diagenetic evolution. The main diagenetic types include mechanical compaction, cementation by carbonates, quartz and clay minerals, and dissolution which have directly influenced the reservoir quality. In the early diagenetic period, the rapid compaction and cementation of carbonate had rapidly destroyed the reservoir quality, while the particles lining of chlorites had protected the reservoir space. In the middle diagenetic stage A, secondary dissolution pores were
\end{abstract}

Lin Chen

chenlin676@163.com

1 Key Laboratory of Tectonics and Petroleum Resources of Ministry of Education, China University of Geosciences (Wuhan), Wuhan 430074, Hubei, China

2 Faculty of Earth Resources, China University of Geosciences (Wuhan), Wuhan 430074, Hubei, China

3 Wuhan Center of China Geological Survey, Wuhan 430205, Hubei, China

4 School of Geosciences, Yangtze University, Wuhan 430100, Hubei, China

5 Exploration and Development Institute, Huabei Branch Company of SINOPEC, Zhengzhou 450006, Henan, China formed as soluble clastic grains were dissolved by the acidic fluid with organic matters maturation. The dissolution has played a constructive role for the pore generation and preservation. In the middle diagenetic stage $\mathrm{B}$, the later compaction and cementation further reduced the reservoir quality. The analysis of pore evolution demonstrates that the initial reservoir porosity is about $30.59 \%$. $16.925 \%$ overall porosity is lost through compaction, $11.65 \%$ porosity loss is due to cementation, and $6.36 \%$ porosity was created by dissolution. Finally, the reservoir is holding $8.375 \%$ porosity in present.

Keywords Ordos basin - Yanchang Formation - Tight sandstone $\cdot$ Diagenesis $\cdot$ Porosity evolution

\section{Introduction}

Low-permeability reservoir is one of the most important types of oil and gas reservoirs throughout the world; wherein China, low-permeability reservoir is mainly developed in the Songliao basin, Bohai Bay basin, Ordos basin and Junggar basin (Spencer 1989; Shanley et al. 2004; Dai et al. 2012). Oil reserves of low-permeability reservoir account for about $36 \%$ of the total proven reserves in China (Zhao et al. 2007). Recently, a series of large-scale low-permeability hydrocarbon reservoirs of Yanchang formation was discovered in Ordos basin. Its complex diagenetic process and oil accumulation mechanism have been the hotspot of oil exploration and development in China (Zou et al. 2013; Yang et al. 2013). The upper Triassic Yanchang formation develops a typical continental tight sandstone reservoir. The Chang 8 oil group of Yanchang formation is the major oil-producing layer in the southwest of the basin which mainly develops 
distributary channel sand bodies. It is characterized by ultra-low permeability and low permeability (Zhang and Ding 2010; Deng et al. 2011). The Chang 8 oil reservoir is mainly composed of fine sandstone with strong heterogeneity. During the burial process, the reservoirs experienced multiple diagenetic-induced superimposed transformations which directly influence on the development and preservation of primary and secondary pore space of the reservoir and hence determine the quality of the present reservoir (Luo et al. 2002; Morad et al. 2010; Awilsa and Luiz 2015; Baig et al. 2016). Therefore, the study of the diagenetic processes and its controlling factors is of great significance to predict high-quality and favorable reservoir of low-permeable Chang 8 tight sandstone. Previous are mainly focused on reservoir characteristics, diagenesis, oil accumulation model and mechanism of the Chang 8 oil group in study area (Zeng and Li 2009; Yao et al. 2013). However, the diagenetic modification to the reservoir physical property and the reservoir evolution pattern are not as well known. Hence, based on the analysis of thin section, scanning electron microscope and physical property testing, this study focuses on the diagenesis characteristics and diagenetic evolution process of Chang 8 tight sandstone in southwestern Ordos basin. Combining with the evolution of reservoir pore, this paper also attempts to reveal the development pattern between diagenetic influence and reservoir pore evolution so as to carry out comprehensive reservoir evaluation and prediction of favorable area in study area.

\section{Geological setting}

The study area is located in the southwest of the Ordos basin. The structural division stretches across the Tianhuan depression, Yishan slope and Weibei uplift of current basin (Fig. 1). During the late Triassic period, Ordos basin developed a set of lacustrine and delta sedimentary fillings under the background of a stable inland Craton. The lithology is primarily composed of a set of gray green or gray medium or thick-bedded blocky fine sandstones or siltstones and dark gray or dark mudstones (Luo et al. 2008). On the whole, the filling of Yanchang Formation records the processes of formation, expansion, contraction and extinction of a large freshwater lake. The basin is large in scale with gentle slope, and the depositional environment is shallow water (Zou et al. 2012). After the previous regional flooding of Chang 9 period, Chang 8 oil group developed a set of progradational or aggradational delta filling sequences which is mainly influenced by the material source system and paleocurrent from the southwestern margin of the basin. The strata display lateral stability. After Chang 8 period, study area developed the Chang 7 deep lake oil shale which is the principal source rock of Yanchang Formation. Due to the good matching relationship between the upper and lower strata, the Chang 8 oil group constitutes the most important oil production layer in study area (Zhang et al. 2006).

\section{Results}

\section{Reservoir characteristics}

Based on the thin section observation, the main types of reservoir rocks of Chang 8 oil group are feldspathic litharenite and lithic arkose according to Folk (Fig. 2) (Folk 1968). Lithology is mostly dominated by fine sandstones. Quartz, feldspar, lithic fragments and black mica are the major components of the detrital grains. The average content of the above mineral is $40,27.3,28.7$ and $4 \%$, respectively. The reservoir contains high lithic fragments, high feldspar and low compositional maturity. The cements mainly compose carbonate, clay minerals and silicon, ranging from 0 to $20 \%$ with average content up to $16 \%$ (Fig. 3). The carbonate cements constitute about $44.7 \%$ of the total cements with low matrix content, generally less than $4 \%$. Quartz is mostly composed of single crystal quartz. Feldspar is composed of a large number of $\mathrm{K}$-feldspar and scarce plagioclases. The rock fragments are dominated by volcanic rock and also contain a small amount of metamorphic rock and sedimentary rock. Detrital grains are poorly sorted, sub-angular or sub-rounded, clasts supported. Grains are in contact as point-to-long or long (Fig. 5a). Cementation type is generally pore cementation. Debris locally distribute in orientation. The preceding analysis shows that the reservoir generally develops the characteristics of low compositional maturity and low textural maturity.

The analysis of thin section and scanning electron microscope suggests that intergranular pore, intergranular dissolution pore and feldspar or debris dissolution pore are the main pore types of Chang 8 sandstone in study area, and the average rate of face porosity is about $4.69 \%$. The porosity ranges from $0.3 \%$ to $19.2 \%$, with an average of $9.06 \%$. The permeability ranges from $0.009 \times 10^{-3} \mu \mathrm{m}^{2}$ to $7.51 \times 10^{-3} \mu \mathrm{m}^{2}$, with an average of $0.2308 \times 10^{-3} \mu \mathrm{m}^{2}$ (Fig. 4). Overall, the reservoir demonstrates strong heterogeneity, low porosity or ultra-low porosity and ultralow permeability, suggesting it belongs to the category of tight sandstone reservoir (Jia et al. 2012).

\section{Diagenesis types and characteristics}

Through the comprehensive analysis of Chang 8 tight sandstone under electron microscopic in study area, the 


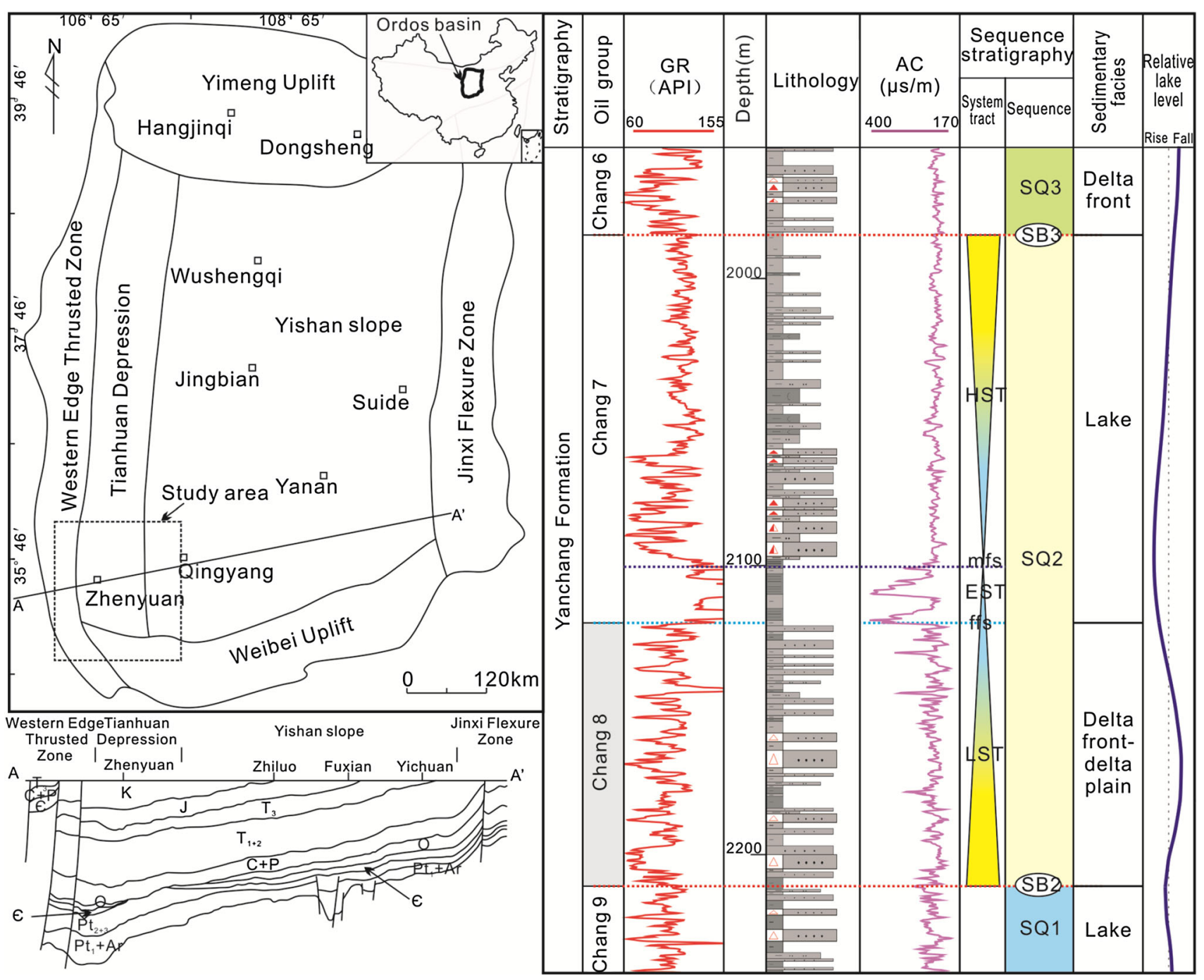

Fig. 1 Location, tectonic units of Ordos basin and sedimentary sequence of Chang 8 oil group of Yanchang Formation in study area

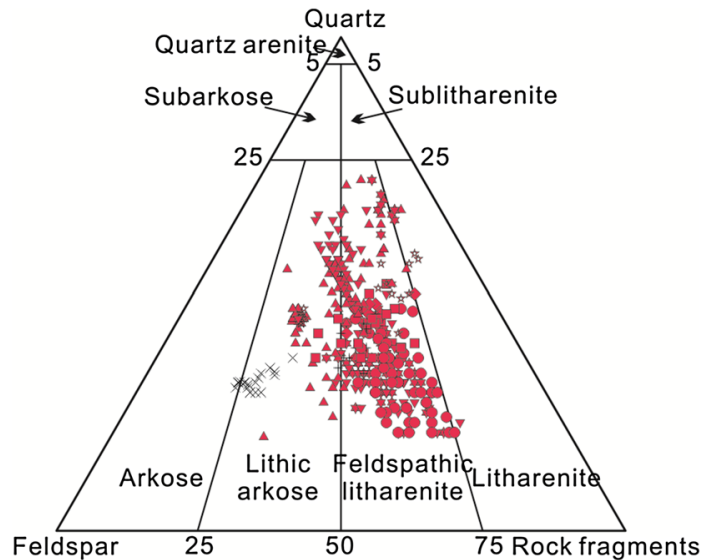

Fig. 2 Detrital composition of Chang 8 oil group reservoir of Yanchang Formation in southwestern Ordos basin (after Folk 1968)



Fig. 3 Cement types and its relative amount of Chang 8 oil group sandstone of Yanchang Formation in southwestern Ordos basin 


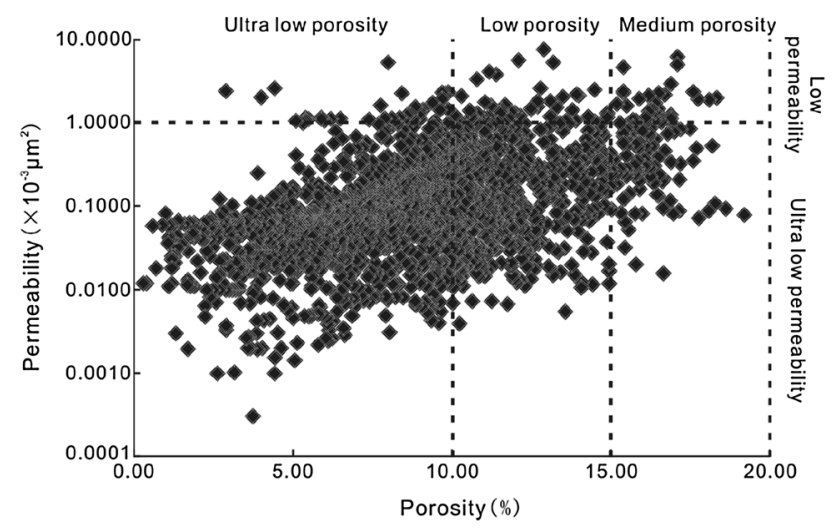

Fig. 4 A plot of porosity versus permeability for Chang 8 oil group reservoir of Yanchang Formation in southwestern Ordos basin

reservoir properties are mainly influenced by diagenesis after the deposition of the reservoir. The diagenesis controls the development, preservation and transformation of primary pores and secondary pores in various degrees (Surdam et al. 1989; He et al. 2010). Based on the observations under microscope, it reveals that compaction, cementation, dissolution and replacement are the major diagenetic types in the study area. And the former two are relatively intense and common that significantly influence pore evolution, and the latter two are relatively weak and show great variance across the reservoir.

\section{Compaction}

The mechanical compaction is predominant in Chang 8 tight sandstone of the study area, and local development of pressure dissolutions was seen. Deformations of ductile debris grains under thin slices can be observed which mostly appeared as bending, elongation and embedding of mudstone, volcanic rock and black mica (Fig. 5a). They could also form intergranular false matrices filling when they entered the pore space. The development of the pressure dissolutions are chiefly existed as the contact dissolutions on the surface of the cuttings. With locally quartz overgrowths caused by pressure dissolutions, it leads to the decrease of the reservoir properties (Wolela 2010). The development degrees of internal grain texture and external chlorite content have a great influence on the compaction effect. The compression of rock solid ability improves while the grain size is lager, the sorting becomes better, and higher content of chlorite is higher. In general, Chang 8 tight sandstone is showing moderate compaction.

\section{Cementation}

The primary cemented material of Chang 8 tight sandstone are carbonate, a relatively small amount of siliceous mineral and clay mineral cement. On the whole, the development intensity of the cementation is moderate to strong. The development of cementation can cause pore and throat blockage, which has an important influence on the reservoir properties.

The carbonate cements are widespread in study area and mainly composed of authigenic calcite; ferrocalcite and dolomite are rare. Carbonate cement percentage is between $1 \%$ and $20 \%$, and the average ups to $7.18 \%$ (Fig. $5 \mathrm{~b}$ and $5 \mathrm{~d})$. According to the output appearance of carbonate cements, it can be divided into 2 stages (early and late) which is primarily composed of the late stage. The early carbonate cements are characterized by intergranular pore filling in the styles of microcrystalline and powder. The contact relationship between the early carbonate cements and detrital grains is not obvious, which indicates that the cementation took place before the major compaction. The late-stage cementation of carbonate is occurred as the form of continuous crystal particles filling in the intergranular pores or dissolution pores, hence reducing the reservoir properties (Figs. 5b, c, 6f).

The major performances of the silica cements are quartz overgrowth and in situ quartz crystal. The quartz overgrowth shows the characteristics of multi-period with wide variation of size ranging from $150 \mu \mathrm{m}$ to $300 \mu \mathrm{m}$ under the microscope. And the quartz overgrowth is more developed in the reservoir that has relatively higher content of quartz grains in the reservoir. In the study area, the early stage of quartz overgrowth is relatively narrow and weak, while the latestage siliceous cements performance as the characteristics of filling euhedral intergranular and more lager (Figs. 5e, 6a, f). The siliceous cements are relatively more developed in the place where coating chlorite is relatively less developed and black mica is relatively rich. The euhedral microcrystalline quartz aggregates are observed in the intergranular pore and the surface of detrital grains in the style of crystal cluster under microscope (Fig. 5f). The percentage of silica content is general low ranging from 1 to $5 \%$ in study area. Due to the relatively high feldspar and quartz content in the reservoirs, which suggests that silicon might derived from the dissolution of quartz grains or through the transformation of feldspar to kaolinite (Kim et al. 2007).

The clay mineral cements are abundant in the Chang 8 tight sandstone, including chlorite, mixed-layer illitesmectite, kaolinite and illite. Among them, chlorite is the most widespread with absolute average percentage up to $6.3 \%$, followed by the others $1.5,1.46$ and $1.28 \%$, respectively. The chlorite generally exists as leaf shaped lining chlorite coating detrital grains and euhedral leaf like on grain surface or filling in pores between grains (Figs. 5e, $\mathrm{f}, 6 \mathrm{c})$. The former is generally formed in early diagenetic stage of the dissolution of feldspar grains, which plays a dominate role in inhibiting the overgrowth and enrichment 
Fig. 5 Compaction and cementation characteristics of Chang 8 oil group of Yanchang Formation in southwestern Ordos basin. a The grains are in point-to-long or long contacting with each other. There are deformations of plastic debris in the figure; $\mathbf{b}$ the calcite cements occupy the intergranular pores in the form of crystal stock; c the feldspar grains are dissolved in the edge, and the intergranular pores are widely filled by kaolinite. Welldeveloped ankerite cements occur in the right lower part of the figure; $\mathbf{d}$ a lot of lighting orange calcite cements develop in intergranular space under cathode luminescence microscope. Blue lighting $\mathrm{K}$-feldspar is replaced by calcite in locally. The quartz is lighting the brown color; e quartz overgrowth occupies the intergranular pore. The grains surface is coated by leaf shaped chlorites; $\mathbf{f}$ authigenic quartz and kaolinite fill pores. The grains surface is coated by leaf shaped chlorites. ( $Q$ quartz, $F$ feldspar, $R$ rock fragments, Cal calcite, Qo quartz overgrowth, Ank ankerite, $K I$ kaolinite, $C h$ chlorite)
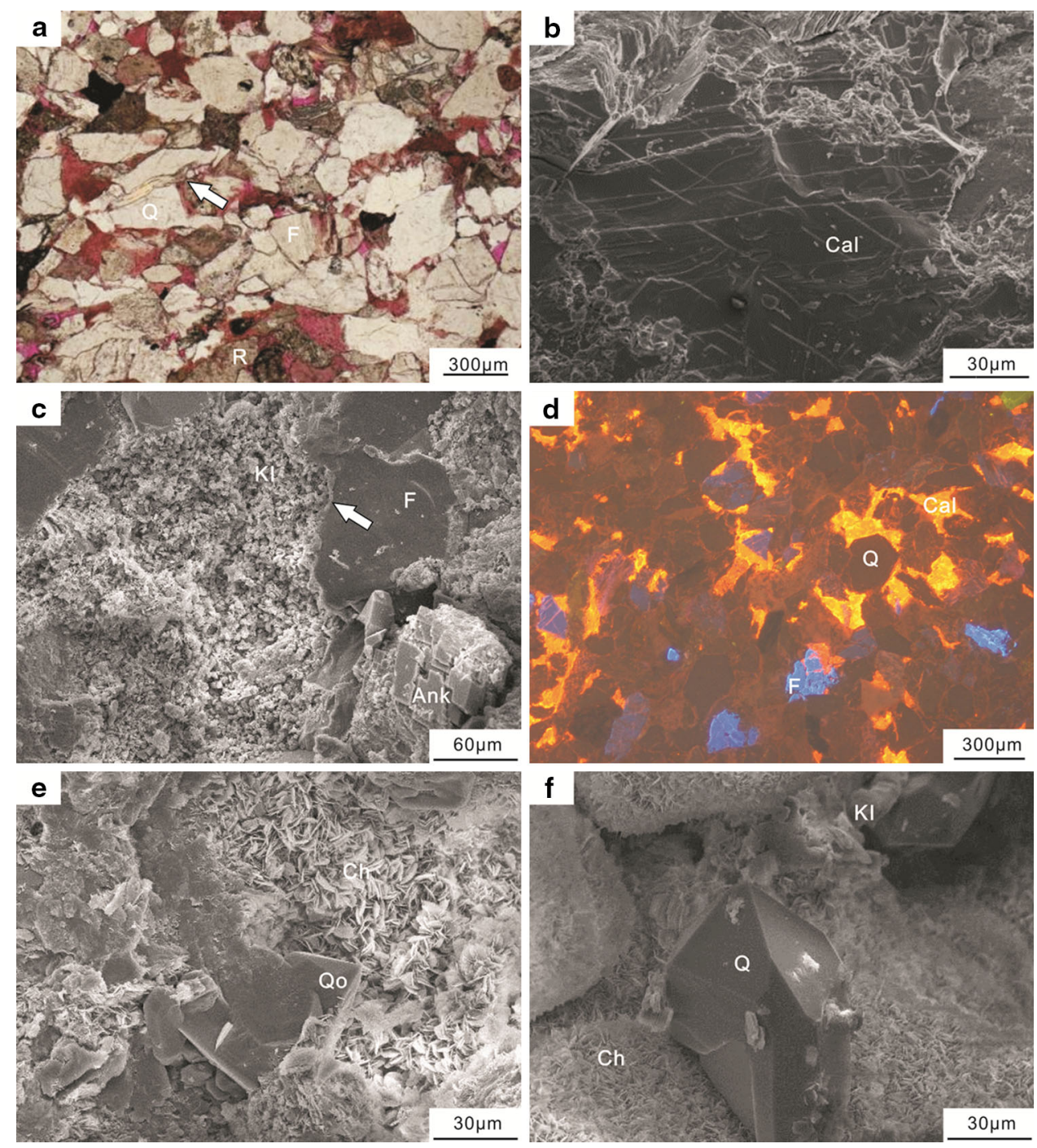

of grains in later period so as to protect the primary intergranular pores (El-ghali et al. 2006). The formation time of latter is relatively late with low content in study area. Generally, the chlorite mainly plays a constructive role for the pore evolution, which performs as inhibiting the growth of the grain and resisting the development of compaction. The mixed-layer illite-smectite mineral mainly fills the intergranular pore with the shape of cellular, curly or filiform under scanning electron microscope. It often originates from the combination of montmorillonite, and $\mathrm{K}^{+}$and $\mathrm{Al}^{3+}$ released from the dissolution of feldspars, micas and other minerals in alkaline or weak alkaline environment. Thus, its appearance suggests that the diagenetic environment tends to alkaline or week alkaline environment. The kaolinite chiefly occurs in the primary residual intergranular pores and secondary dissolution pores with the shape of pseudo-hexagonal plates, book-like or vermicular in study area (Figs. 5c, 6d). It generally forms in the alteration and transformation of feldspar grains in acidic fluid environment, indicating the development of acidic diagenetic environment in the process of diagenesis evolution (Worden and Burley 2003; Hammer et al. 2010). The illite mainly exists on the surface of detrital grains with the shape of curly or silk thread under scanning electron microscope. There are also pore bridging of illites so as to cause the reservoir pore throat blockage and the reduction of reservoir property (Fig. 6e). The illite generally originates from the transformation of other clay minerals in K-rich, alkaline and weak alkaline environment. The relatively high content of illite indicates that the reservoir is in relatively late diagenetic stage which is in alkaline or alkaline environment.

\section{Dissolution}

Based on the observation of common slice, casting thin section, cathode luminescence and scanning electron microscope of Chang 8 tight sandstone, it shows that the 
Fig. 6 Dissolution,

cementation and metasomatism characteristics of Chang 8 oil group of Yanchang Formation in southwestern Ordos basin.

a There are intragranular dissolved pores in feldspar grains. Also, intergranular dissolved pore and residual primary pore (right 2 white arrows) occur in the Chang 8 tight sandstone; $\mathbf{b}$ the intergranular dissolved pores form in rock fragment grain; c grains surface is coated by leaf shaped chlorites and few euhedral authigenic quartz; d authigenic kaolinite with the shape of pseudo-hexagonal plates, book-like or vermicular fills the intergranular pores; e curly or silk thread like illite is bridging in intergranular pores; f quartz overgrowth fills pore. There is calcite replacing feldspar in locally. ( $Q$ quartz, $F$ feldspar, $R$ rock fragments, Cal calcite, Qo quartz overgrowth, $K I$ kaolinite, $C h$ chlorite, $D P$ dissolved pore)
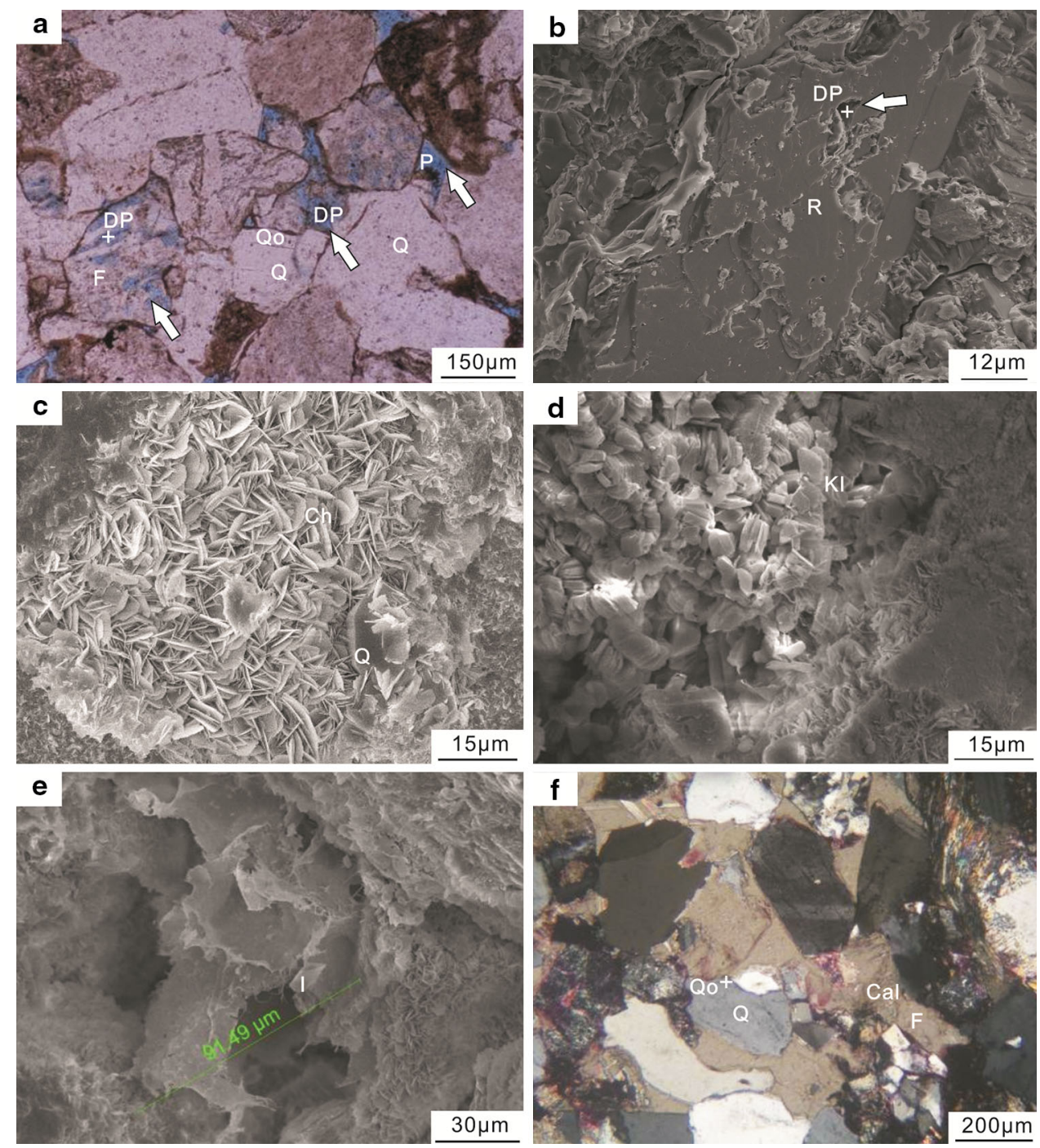

dissolution is more developed. The pore primarily composes intergranular dissolved pore and intragranular dissolved pore which derives from the dissolution of unstable grains, such as volcanic debris, feldspar and carbonate cements. The intergranular dissolved pores are mainly occurred as irregular dissolution of the ductile grains edge with precipitations of kaolinite surrounding the pore (Fig. 5c). The intragranular dissolved pores are mainly manifested by the partly intra dissolution of the debris and feldspar grains with the shape of irregular mottling, banded and cellular. And when the grains are completely dissolved, it forms a moldic pore (Fig. 6a, b). To conclude, the relatively high debris and feldspar content in study area is the material basis for the extensive development of dissolution.

\section{Replacement}

The replacement is primarily featured by the carbonate minerals replacing the volcanic rock debris and feldspar grains so as to form the irregular edge of detrital grains in study area, usually showing that the grain edge of feldspar is replaced by carbonate with the shape of semi-arch or harbor, and the outer edge of quartz grains is with the pronounced shape of dentate (Fig. 6f). Overall, the replacement of carbonate minerals is relatively limited in the samples and has little effect on the physical properties of the reservoir.

\section{Division of diagenetic stage}

The diagenetic stage of the tight sandstone is divided according to the association of clay minerals, transformation degree of mixed layer illite-smectite mineral, organic matter maturity, homogenization temperature of fluid inclusions and rock textural characteristics in study area (Hakimi et al. 2012; Qi et al. 2012; Henares et al. 2014). At present, the average of middle layer ratio $(\% \mathrm{~S})$ of mixed layer illite-smectite minerals for Chang 
8 sandstone is $14 \%$, generally less than $15 \%$. It is believed that mixed layer illite-smectite minerals are in the third transformation zone, and the organic matter is highly mature. This indicates that the reservoir is in the middle diagenetic stage $\mathrm{B}$. The maximum pyrolysis peak of organic matter is between 440 and $461{ }^{\circ} \mathrm{C}$, and average is $448{ }^{\circ} \mathrm{C}$, which indicates that it is in the middle diagenetic stage $\mathrm{A}$. The homogenization temperature of fluid inclusions is mainly distributed between $85-100{ }^{\circ} \mathrm{C}$ and $105-120^{\circ} \mathrm{C}$, which indicates that the reservoir is in the middle diagenetic stage $\mathrm{B}$. Combining the development of illite, Fe-carbonates and multi-stage quartz overgrowth, the grains contact with each other in the forms of point-long or long due to intense compaction which also indicates the reservoir is in the middle diagenetic stage $\mathrm{B}$. Based on the above indicators, we consider that the Chang 8 tight sandstone reservoir is in the middle diagenetic stage $B$ and have experienced 4 diagenetic stages (early diagenetic stage $\mathrm{A}$ and $\mathrm{B}$, middle diagenetic stage $\mathrm{A}$ and $\mathrm{B}$ ). The developing diagenetic sequence is: mechanical compaction $\rightarrow$ the development of lining chlorite $\rightarrow$ quartz overgrowth $\rightarrow$ early pore filling of micritic calcite cements $\rightarrow$ organic acid fluid entry under hydrocarbon generation $\rightarrow$ the dissolution of feldspar, rock fragments and early calcite cements $\rightarrow$ the forming of authigenic kaolinite, siliceous cements $\rightarrow$ the development of illite $\rightarrow$ the cementation of late carbonate and replacement (Fig. 7).

\section{Discussion}

\section{Influence of diagenesis on reservoir pore evolution}

During the burial process, the reservoir has experienced multiple diagenetic transformations which have an important influence on the physical properties of the reservoir. Among them, the influences of compaction, cementation and dissolution are the most significant. The main constructive diagenesises are the dissolution of detrital grain, and the preservation of pore space caused by the grain lining of clay mineral. The destructive diagenesises are the increasing compaction and the decrease of cementation.

\section{Effect of diagenesis on reservoir porosity and permeability}

Due to the low compositional maturity and texture maturity, the primary pores are losing rapidly with the enhancement of compaction further reducing the physical property of the reservoir. Under the intense compaction, the ductile rock fragments and micas were deformed as being squeezed into the pore space forming pseudomatrix and blocking pores, which lead to the poorer pore connectivity, poorer liquidity and poorer permeability. Figure 8 shows the porosity quickly becomes poor with the depth increasing. As the permeability develops a positive correlation between porosity (Fig. 4), it indicates that the physical properties develop a negative relationship with the increasing in compaction. Besides compaction, the
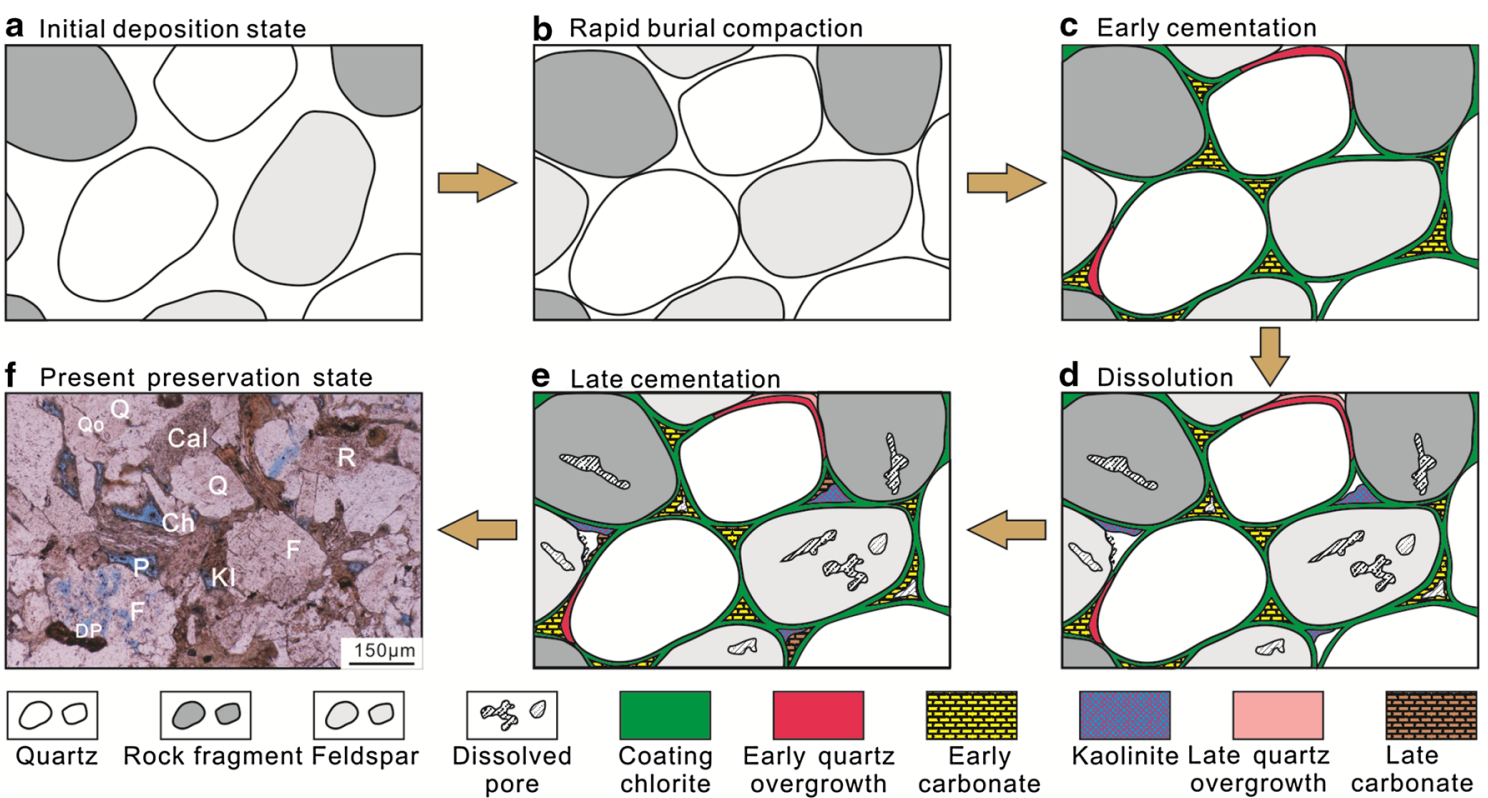



.
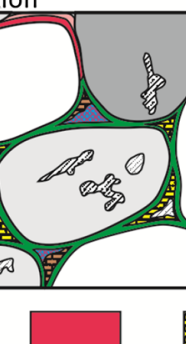

Early quartz overgrowth
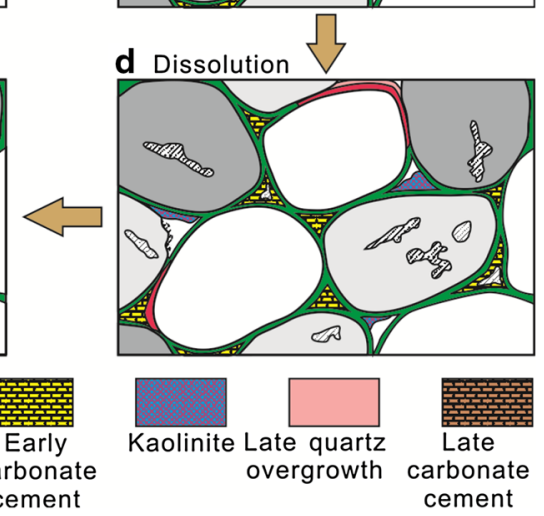

Fig. 7 Schematic diagram of diagenesis and porosity evolution in study area. ( $Q$ quartz, $F$ feldspar, $R$ rock fragments, Cal calcite, $Q o$ quartz overgrowth, $K I$ kaolinite, $C h$ chlorite, $D P$ dissolved pore) 


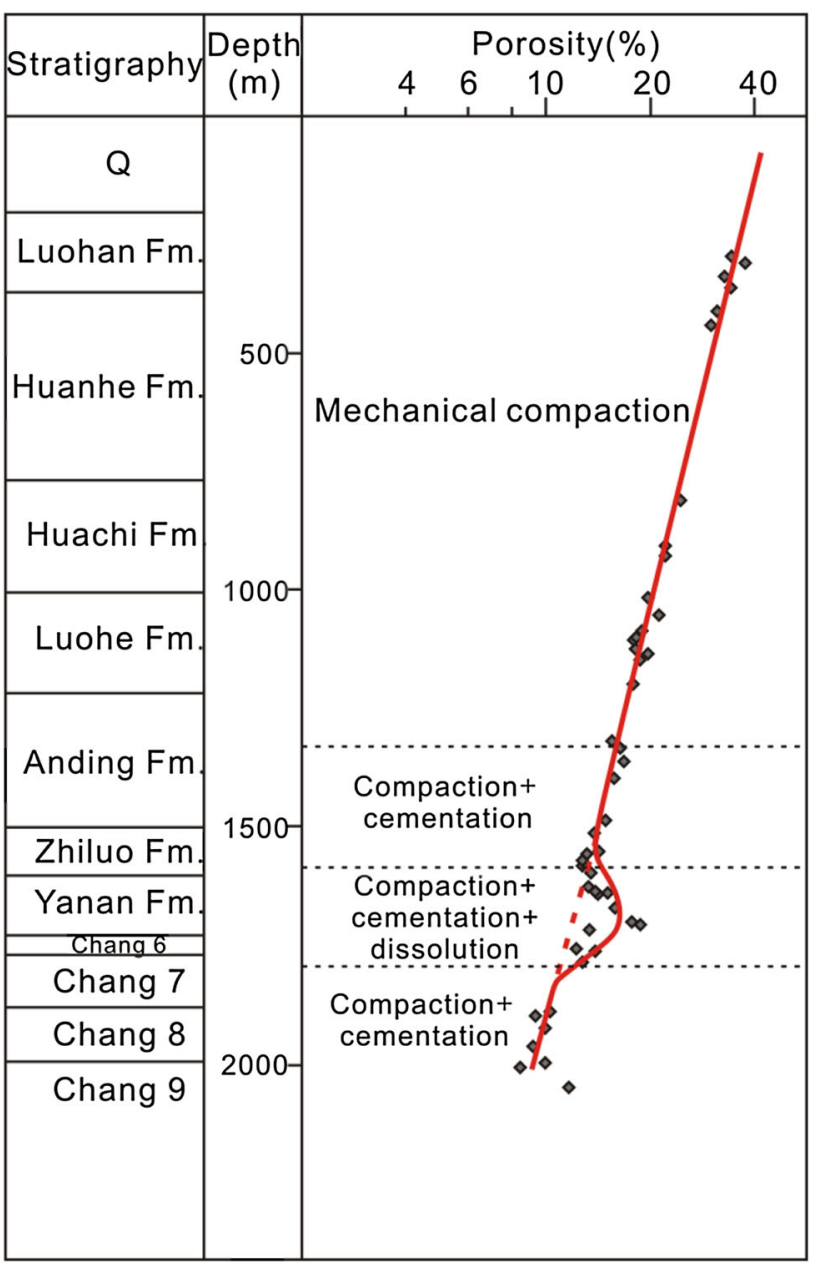

Fig. 8 Relationship between porosity and diagenesis with depth in Chang 8 oil group of Yanchang Formation in southwestern Ordos basin

development of cementation and dissolution in the late stage is side factors suppressing the compaction effects. Refers to the map of the importance of compaction and cementation, it is believed that the rate of porosity loss caused by compaction is on anerage of $58 \%$, and the average amount of porosity loss caused by cementation is $42 \%$ (Fig. 9). The porosity loss resulting from the compaction is dominant.

The cements of the Chang 8 tight sandstone have different degree effect on pore evolution. The carbonate cements are the most developed, which have the most obvious influence on the physical properties of the reservoir. According to the curve of carbonate content and reservoir physical properties, the reservoir porosity and permeability decrease sharply to about $6 \%$ and $0.1 \times 10^{-3} \mu \mathrm{m}^{2}$ when the carbonate content is less than $5 \%$, and the properties changes slightly when it is over $5 \%$ (Fig. 10). This indicates that the carbonate cementation is mainly present as occupying the pore space so as to weaken

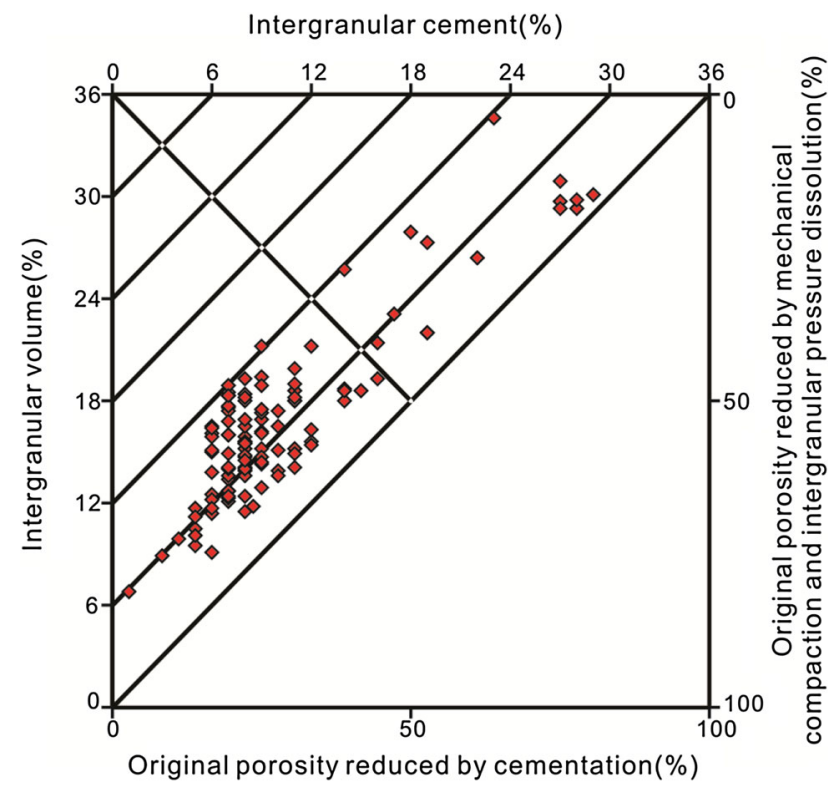

Fig. 9 Influence of compaction and cementation on porosity reduction of reservoirs in Chang 8 oil group of Yanchang Formation in southwestern Ordos basin (after Hancock 1978; Ehrenberg 1990)

the liquidity and decrease the reservoir physical property which is most significant in the early diagenetic period. In the late diagenetic stage, the decreasing is further enhanced by the late carbonate cementation, which leads to the improvement effect of dissolution not obvious.

Clay mineral cements in the early diagenetic stage are mainly developed as lining chlorites coating of detrital grains, and it helped to restrain the grains overgrowth and resist the development of compaction. Figure 11b, shows that the chlorite is good for the preservation of the pore space. In the later diagenetic stage, kaolinite was precipitated from the dissolution of feldspar and debris, while the formation of illite was transformed from early period clay minerals. Clay mineral cements have played a negative role in the pore preservation which is primarily present as occupying the pore space and leads to the poorer porosity. But there is an unobvious influence on permeability (Fig. 11a). With the transformation of illite from early period clay minerals, the bridging of illite destroyed the pore connectivity that further reduces the porosity of the reservoir. However, it is with unobvious influence on the reservoir physical property as its relatively low content. Overall, the cementation of clay minerals was being both constructive and destructive roles for the pore evolution of the study area. As the authigenic precipitations of quartz and feldspar have occupied the pore space, they have a destructive effect on the reservoir physical properties evolution.

In middle diagenetic stage $\mathrm{A}$, a large amount of intragranular dissolved pores and intergranular dissolved pores 

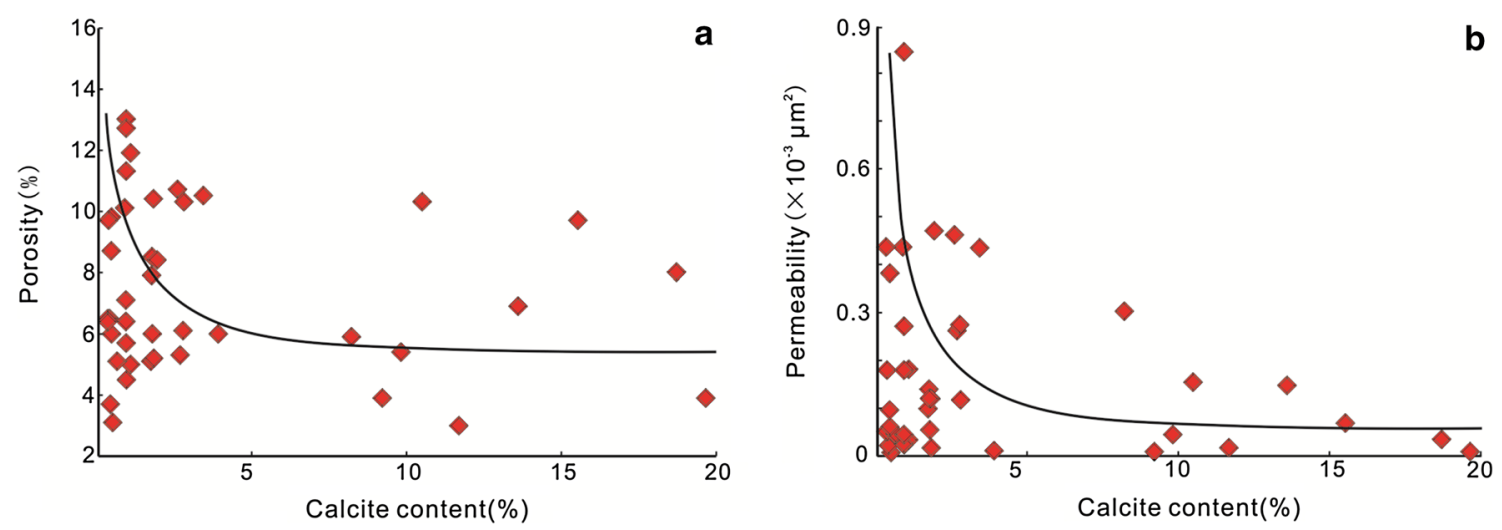

Fig. 10 A plot of calcite content versus porosity (a) and permeability (b) for Chang 8 oil group reservoir of Yanchang Formation in study area
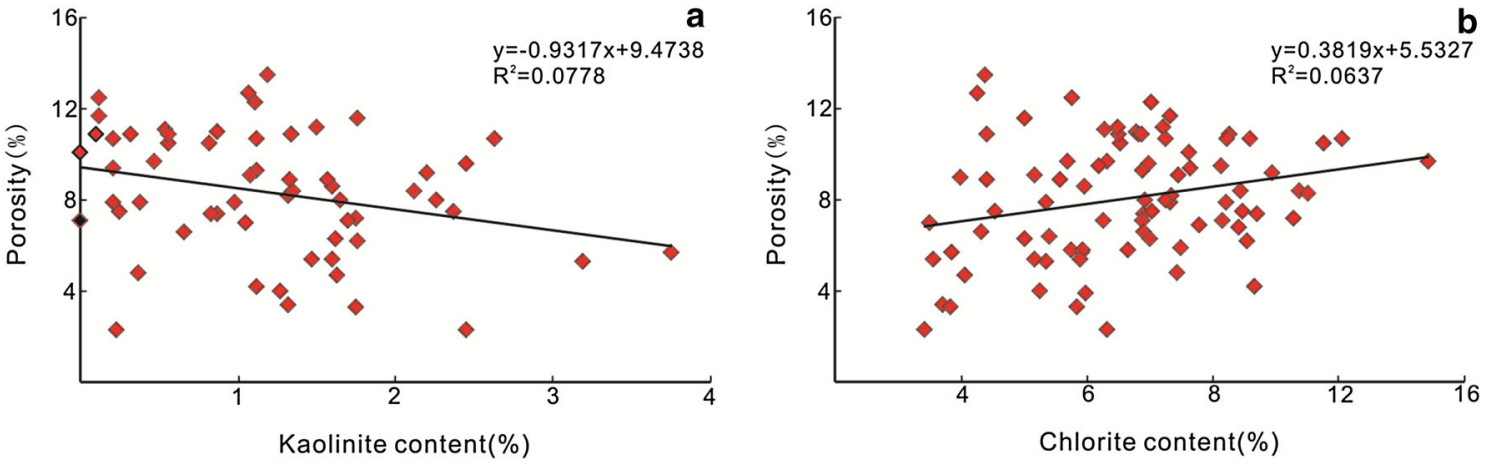

Fig. 11 A plot of kaolinite content (a) and chlorite content (b) versus porosity for Chang 8 oil group reservoir of Yanchang Formation in study area

are developed due to the dissolution of feldspar and volcanic rock fragments caused by the erosion of organic acid and inorganic acid fluid originated from the maturation of organic matter. They constitute the main pore types of the Chang 8 tight sandstone reservoir. Thus, the dissolution acts as a constructive role for the improvement of reservoir physical properties (Fig. 12).

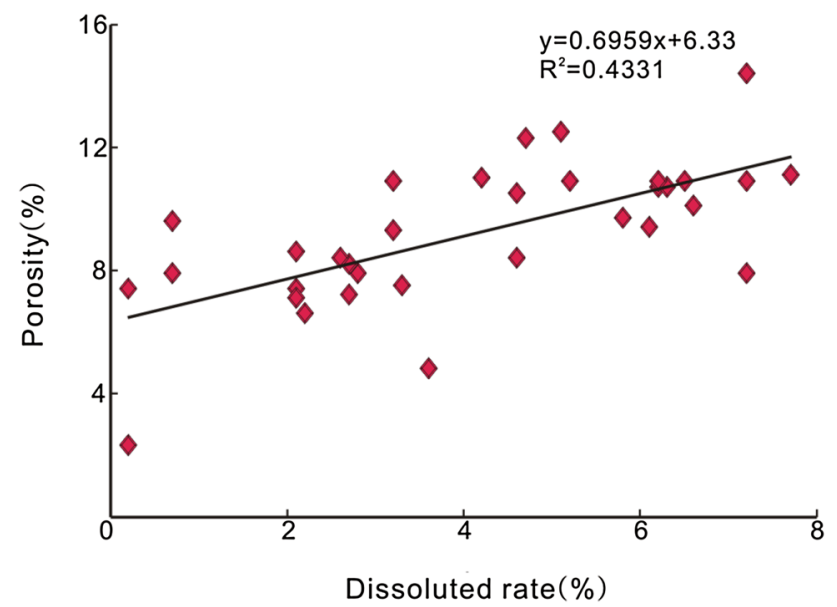

Fig. 12 A plot of dissolution rate versus porosity for Chang 8 oil group reservoir of Yanchang Formation in southwestern Ordos basin

\section{Recovery of reservoir porosity}

The initial porosity of sandstones $\left(\Phi_{0}\right)$ mainly depends on grain size and sorting. The initial porosity of unconsolidated sandstone can be determined by the relationship between the sorting coefficient and porosity of the wet sand at open conditions on the earth surface (Beard and Weyl 1973; Scherer 1987; Zhang et al. 2014a, b)

$\Phi_{0}=20.91+22.90 / S_{0}, \quad S_{0}=\left(Q_{1} / Q_{2}\right)^{1 / 2}$

$S_{0}$ is the sorting coefficient of Trask. It can be obtained from the experimental data of sieve method. $Q_{1}, Q_{2}$ are, respectively, for the grain size on cumulative relative curve corresponding to the content of $25 \%$ and $75 \%$. According to the large number of grain size analysis results, it shows that the Chang 8 tight sandstone is poor sorted, and the sorting coefficient is ranging from 1.71 to 4.5 . The initial porosity of reservoir is between $26 \%$ and $34.3 \%$, with $30.59 \%$ in average. The experiment result matches the result $(30.7 \%)$ deriving from the Beard and Weyl laboratory statistical methods for the study of poorly sorted sandstone (Zhang et al. 2014a, b). This proves that the estimated value is reliable. 
Mechanical compaction lasted through the entire diagenetic history. The amount of porosity reduction should be estimated in different stages of diagenesis evolution. Theoretically, the pore space is continuously decreasing along the development of compaction; they are inversely correlated (Athy 1930). The residual porosity can be expressed as the list.

$\Phi_{c}=\Phi_{0} \cdot e^{-C \cdot Z}$

$C$ is the compaction coefficient. The reservoir is mainly composed of fine sand and very fine sand, and the $C$ is noted as 0.00034 (Hegarty et al. 1988). $Z$ is the depth of buried. Combined with the burial history curve of the study area, the maximum burial depth of each diagenetic stage is at $1330 \mathrm{~m}$ (early diagenetic stage A), $1570 \mathrm{~m}$ (early diagenetic stage B), $2080 \mathrm{~m}$ (middle diagenetic stage A), $2370 \mathrm{~m}$ (middle diagenetic stage $\mathrm{B}$ ). The corresponding porosities at the end of each stage are 19.462, 17.937, 15.082 and $13.665 \%$. Because the content of the cements in study area is greater than $5 \%$ and the development of cementation has a certain degree of inhibition to the development of compaction, the actual value of porosity reduction caused by compaction is less than the above calculated value.

The porosity reduction of cementation mainly caused by pore filling of carbonate, silica and clay minerals is roughly equal to their content, which is about $11.65 \%$.

The dissolution of detrital grains and interstitial matter has improved the reservoir property by forming secondary pores. The increase of the porosity $\left(\Phi_{4}\right)$ can be estimated by the rate of face dissolved pore $(\eta)$, total rate of face porosity $(T \eta)$ and testing porosity $(\Phi)$.

$\Phi_{4}=\eta / T \eta \times \Phi$

The statistics data of the thin slice show that the average increased porosity caused by dissolution in the study area is $6.36 \%$.

\section{Analysis of reservoir pore evolution}

The initial porosity of reservoir is mainly controlled by the characteristics of initial sediments and deposition conditions, and the pore evolution in late stage mainly depends on the intensity of late diagenesis. Based on the above analysis, it is believed that the pore evolution of the Chang 8 tight sandstone reservoirs in study area takes the following features.

During the early diagenetic stage A, the reservoir experienced rapid subsidence and uplifting. The maximum burial depth was shallow and was about $1330 \mathrm{~m}$ (Fig. 13). The compaction was dominant in the reservoir, where the cementation effect was relatively minor in this stage. The pore water was discharged with the porosity decreasing sharply which is about $11.128 \%$ under intense compaction. The early weak quartz overgrowth and grain lining chlorites composed the main cementations at this stage. The debris grains were in point contact. The pores were dominated by residual intergranular pores.

During the early diagenetic stage $B$, the buried depth continued to increase to $1570 \mathrm{~m}$ (Fig. 13). The cementation effect became dominating in this stage, and carbonate cements and quartz overgrowth were mainly attributed to the poor physical properties. The debris grains were in point-long contact. The pores were chiefly composed of residual intergranular pores and a small amount of secondary dissolved pores. Early precipitated clay minerals gradually transformed to mixed layer illite-smectite mineral. According to the above estimates, the porosity loss due to compaction was $1.525 \%$ in this stage. The porosity loss caused by the pore filling of chlorite, early carbonate cements and early quartz overgrowth was approximately equal to their volume fraction of $3.8 \%$.

During the middle diagenetic stage $\mathrm{A}$, the maximum buried depth of the reservoir reached $2080 \mathrm{~m}$, and the diagenetic temperature was between 85 and $110{ }^{\circ} \mathrm{C}$ (Fig. 13). Large amount of acid fluid was brought into the reservoir due to the hydrocarbon generation of the mature of organic matters which had dissolved the soluble components. Among them, the impact of compaction was increasing, so as to cause the porosity loss of $2.855 \%$. Intergranular dissolved pores and intergranular dissolved pores were well developed which made the porosity increasing about $6.36 \%$. The newly formed mixed-layers of illite-smectite were primarily transformed from early clay minerals, which have little effect on the porosity. However, the kaolinite derived from the dissolution was mainly formed in this stage, which constituted the main reason for the pore filling. It had caused porosity loss about $2.5 \%$ which was similar to its volume fraction.

During the middle diagenetic stage B, the strata buried depth continued to increase and then slowly uplifted. The highest diagenetic temperature tended to be $120{ }^{\circ} \mathrm{C}$ (Fig. 13). As the organic matter was over mature, the hydrocarbons charging was significantly weakened. The diagenetic environment gradually transformed to weak alkaline. The Fe-carbonate cements began to form. Chlorite content was reduced corresponding to the intergranular precipitations of illite. The debris grains were in point-long or long contact. The residual intergranular pores, intergranular dissolved pores and intergranular dissolved pores are the main pore types of the reservoir. The porosity loss due to compaction was estimated to be $1.417 \%$. And the porosity loss caused by cementation was close to the late cements volume fraction which was about $5.35 \%$. The reservoir became densification at this stage. 


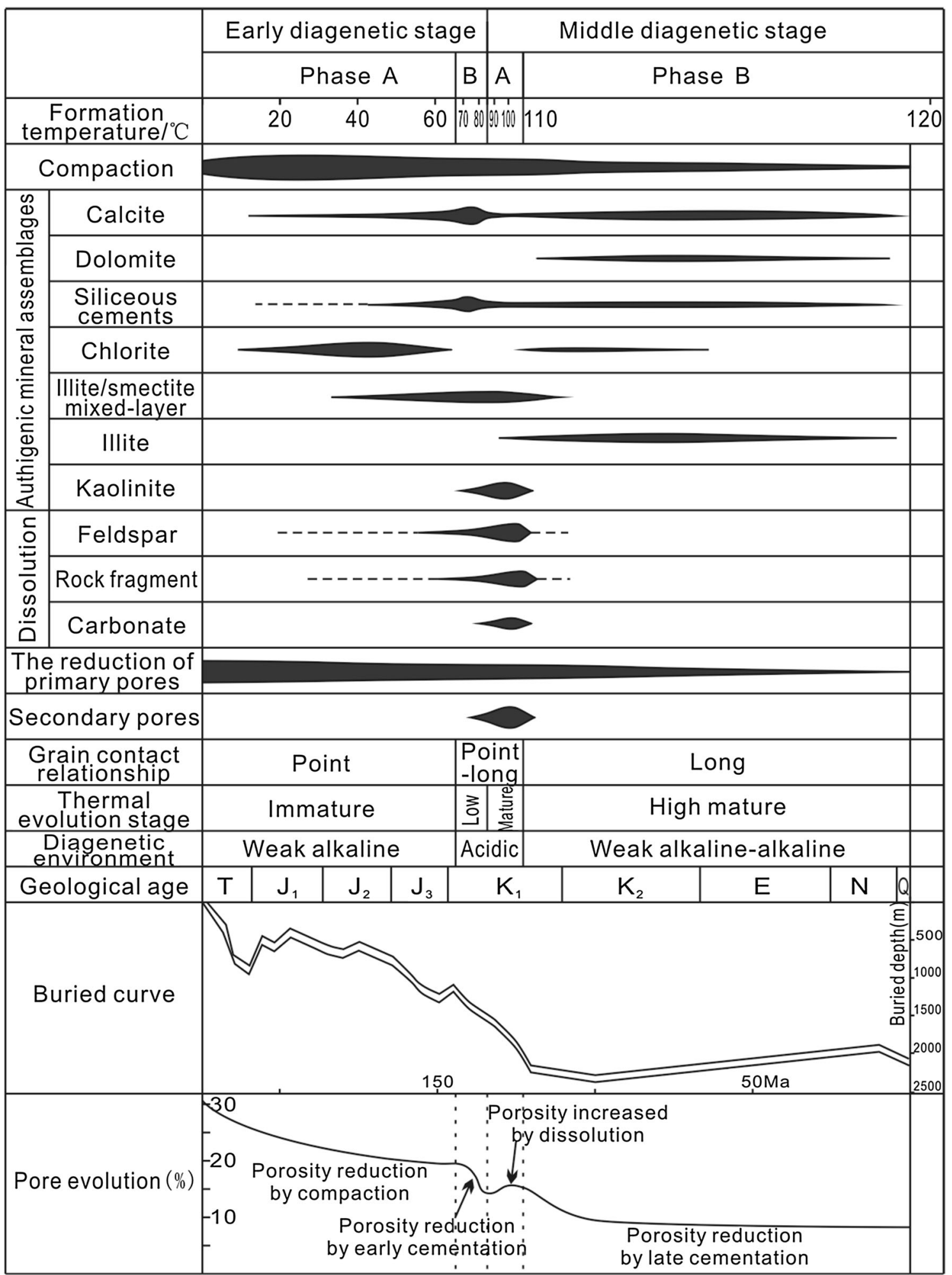

Fig. 13 Schematic diagram of diagenetic stage division and pore evolution for Chang 8 oil group reservoir of Yanchang Formation in study area

In summary, the Chang 8 tight sandstone develops relatively intense compaction and cementation, as well as the typical feldspar and rock fragments dissolution during the diagenetic evolution. The sediments experienced burial series of compaction, early cementation, dissolution and late cementation during burial. The initial porosity of the reservoir is about $30.59 \%$. The compaction has run through the entire process of pore evolution and has caused the 
porosity loss of about $16.925 \%$ which is most obvious in the early diagenetic stage. The porosity loss caused by the cementation of carbonate, silicon and clay mineral is about $11.65 \%$. The porosity improvement caused by the dissolution is about $6.36 \%$. The final remaining porosity is about $8.375 \%$ at the end of the diagenesis $\mathrm{B}$, and it is close to the average testing result $9.06 \%$ of a large numbers of samples. The error may occur as statistical errors of pores, dissolution face rate, cementation content and the coverage of the selected testing samples.

\section{Conclusions}

The main types of reservoir rocks of Chang 8 oil group are feldspathic litharenite and lithic arkose in southern Ordos basin. The reservoir generally develops the characteristics of low compositional maturity and textural maturity. The reservoir is characterized by low porosity or ultra-low porosity and ultra-low permeability, which belongs to tight sandstone reservoir. Currently, the reservoir is in the middle diagenetic stage B. The compaction was the key factor for the rapid deterioration of reservoir physical property in the early diagenetic stage A. The carbonate cements are the most significant damaging effect to the pore space in all cementation. The pore filling of siliceous cements and authigenic clay mineral cements destroyed the reservoir physical properties to a certain extent. The early grain lining chlorite and the late dissolution constitute the constructive role for the reservoir physical property evolution. In the middle diagenetic stage $\mathrm{A}$, the acidic fluid was discharged from mature hydrocarbon favouring the development of secondary dissolved pores and hence substantially improving physical properties of the reservoir. During the middle diagenetic stage $B$, the development of late-stage cementation and compaction further reduce the reservoir quality. In the process of diagenetic evolution, the initial porosity of reservoir is about $30.59 \%$ and the porosity loss caused by compaction and cementation is approximately $16.925 \%$ and $11.65 \%$, respectively, while the porosity increase by dissolution is about $6.36 \%$. Under the combination of the above multi-stage diagenesises, the characteristics of tight reservoir are formed at last.

Acknowledgments This research is granted by the National Natural Science Foundation of China (Grant No. 41002045). We are grateful to thank anonymous reviewers for their constructive comments which greatly improved the manuscript.

Open Access This article is distributed under the terms of the Creative Commons Attribution 4.0 International License (http:// creativecommons.org/licenses/by/4.0/), which permits unrestricted use, distribution, and reproduction in any medium, provided you give appropriate credit to the original author(s) and the source, provide a link to the Creative Commons license, and indicate if changes were made.

\section{References}

Athy LF (1930) Density, porosity, and compaction of sedimentary rocks. AAPG Bull 14(1):1-24

Awilsa De Sousa GC, De Ros LF (2015) Diagenesis of Aptian sandstones and conglomerates of the Campos basin. J Pet Sci Eng 125:189-200

Baig MO, Harris NB, Ahmed H, Baig MOA (2016) Controls on reservoir diagenesis in the Lower Goru Sandstone Formation, Lower Indus basin, Pakistan. J Pet Geol 39(1):29-47

Beard DC, Weyl PK (1973) Influence of texture on porosity and permeability of unconsolidated sand. AAPG Bull 57(2):349-369

Dai JX, Ni YY, Wu XQ (2012) Tight gas in china and its significance in exploration and exploitation. Pet Explor Dev 39(3):277-284

Deng XQ, Fu JH, Yao JL, Pang JL, Sun B (2011) Sedimentary facies of the middle-upper Triassic Yanchang Formation in Ordos basin and breakthrough in petroleum exploration. J Palaeogeogr 13(4):443-455 (in Chinese with English abstract)

Ehrenberg SN (1990) Relationship between diagenesis and reservoir quality in sandstones of the Garn formation, Haltenbanken, midNorwegian continental shelf. AAPG Bull 74(10):1538-1558

El-ghali MAK, Mansurbeg H, Morad S, Al-aasm I, Ramseyer K (2006) Distribution of diagenetic alterations in glaciogenic sandstones within a depositional facies and sequence stratigraphic framework: evidence from the upper Ordovician of the Murzuq basin, SW Libya. Sediment Geol 190(1):323-351

Folk RL (1968) Petrology of sedimentary rocks. Hemphill Publishing Company, Austin

Hakimi MH, Shalaby MR, Abdullah WH (2012) Diagenetic characteristics and reservoir quality of the Lower Cretaceous Biyadh sandstones at Kharir oilfield in the western central Masila basin, Yemen. J Asian Earth Sci 51:109-120

Hammer E, Mork MBE, Naess A (2010) Facies controls on the distribution of diagenesis and compaction in fluvial-deltaic deposits. Mar Pet Geol 27(8):1737-1751

Hancock NJ (1978) Possible causes of Rotliegend sandstone diagenesis in northern West Germany. J Geol Soc 135(1):35-40

He YX, Zhang W, Hu ZW, Lan YF, Huang PP (2010) Affect of feldspar dissolution to properties of sandstone reservoir of Chang 8 oil layer in Jiyuan area, Ordos basin. Nat Gas Geosci 3:22 (in Chinese with English abstract)

Hegarty KA, Weissel JK, Mutter JC (1988) Subsidence history of Australia's southern margin: constraints on basin models. AAPG Bull 72(5):615-633

Henares S, Caracciolo L, Cultrone G, Fernandez J, Viseras C (2014) The role of diagenesis and depositional facies on pore system evolution in a Triassic outcrop analogue (SE Spain). Mar Pet Geol 51:136-151

Jia CZ, Zheng M, Zhang YF (2012) Unconventional hydrocarbon resources in China and the prospect of exploration and development. Pet Explor Dev 39(2):129-136

Kim JC, Lee YI, Hisada K (2007) Depositional and compositional controls on sandstone diagenesis, the Tetori group (middle Jurassicearly Cretaceous), central Japan. Sediment Geol 195(3):183-202

Luo JL, Morad S, Zhang XL, Yan SK, Wu FL, Li YH, Xue JM (2002) Reconstruction of the diagenesis of the fluvial-lacustrinedeltaic sandstones and its influence on the reservoir quality evolution. Sci China Earth Sci 45(7):616-634

Luo JL, Li ZX, Shi CE, Li J, Han YL, Wang HH, Li JB, Wang CY (2008) Depositional systems and provenance directions for the Chang 6 and Chang 8 reservoir groups of the upper Triassic Yanchang Formation in the southwestern Ordos basin. Geol Bull China 27(1):101-111

Morad S, Ai-ramadan K, Ketzer JM, Ros LFD (2010) The impact of diagenesis on the heterogeneity of sandstone reservoirs: a review 
of the role of depositional fades and sequence stratigraphy. AAPG Bul 94(8):1267-1309

Qi YA, Wang M, Zheng W, Li D (2012) Calcite cements in burrows and their influence on reservoir property of the Donghe sandstone, Tarim basin, China. J Earth Sci 23:129-141

Scherer M (1987) Parameters influencing porosity in sandstones: a model for sandstone porosity prediction. AAPG Bull 71(5):485-491

Shanley KW, Cluff RM, Robinson JW (2004) Factors controlling prolific gas production from low-permeability sandstone reservoirs: implications for resource assessment, prospect development, and risk analysis. AAPG Bull 88(8):1083-1121

Spencer CW (1989) Review of characteristics of low-permeability gas reservoirs in western United States. AAPG Bull 73(5):613-629

Surdam RC, Crossey LJ, Hagen ES, Heasler HP (1989) Organicinorganic interactions and sandstone diagenesis. AAPG Bull $73(1): 1-23$

Wolela A (2010) Diagenetic evolution of the Ansian-Pliensbachian Adigrat Sandstone, Blue Nile basin, Ethiopia. J Afr Earth Sci 56(1):29-42

Worden RH, Burley SD (2003) Sandstone diagenesis: the evolution of sand to stone. Sandstone Diagenesis Recent Anc 4:3-44

Yang WW, Liu GD, Liu XY (2013) The accumulation mechanism and accumulation models of oil in low permeability reservoir of Yanchang Formation in Longdong area, Ordos basin. Earth Sci Front 20(2):132-139 (in Chinese with English abstract)

Yao JL, Deng XQ, Zhao YD, Han TY, Chu MJ, Pang JL (2013) Characteristics of tight oil in Triassic Yanchang Formation, Ordos basin. Pet Explor Dev 40(2):161-169

Zeng LB, Li XY (2009) Fractures in sandstone reservoirs with ultralow permeability: a case study of the upper Triassic Yanchang Formation in the Ordos basin, China. AAPG Bull 93(4):461-477
Zhang SN, Ding XQ (2010) Characters and causes of tight sandstones of Yanchang Formation in southern Ordos basin. J Chengdu Univ Technol (Sci Technol) 37(4):386-394 (in Chinese with English abstract)

Zhang WZ, Yang H, Li JF, Ma J (2006) Leading effect of high-class source rock of Chang 7 in Ordos basin on enrichment of low permeability oil-gas accumulation-hydrocarbon generation and expulsion mechanism. Pet Explor Dev 33(3):289-293

Zhang C, Sun W, Gao H, Xi TD, He QY, Shi JC, Qu L (2014a) Quantitative calculation of sandstone porosity evolution based on thin section data: a case study from Chang 8 reservoir of Huanjiang area, Ordos basin. Acta Sediment Sin 32(2):365-375 (in Chinese with English abstract)

Zhang XL, Tian JC, Wang F, Chen R, Zhang JQ (2014b) Diagenetic characteristics and quantitative porosity estimation of tight sandstone reservoirs: a case from the 8th member of Permian Xiashihezi formation in the Gaoqiao region, Ordos basin. Oil Gas Geol 35(2):212-217 (in Chinese with English abstract)

Zhao JZ, Wu SB, Wu FL (2007) The classification and evaluation criterion of low permeability reservoir: an example from Ordos basin. Lithol Reserv 3:6 (in Chinese with English abstract)

Zou CN, Wang L, Li Y, Tao SZ, Hou LH (2012) Deep-lacustrine transformation of sandy debrites into turbidites, upper Triassic, Central China. Sediment Geol 265:143-155

Zou CN, Zhang GS, Yang Z, Tao SZ, Hou LH, Zhu RK, Yuan XJ, Ran QQ, Li DH, Wang ZP (2013) Geological concepts, characteristics, resource potential and key techniques of unconventional hydrocarbon: on unconventional petroleum geology. Pet Explor Dev 40(4):385-399 